\title{
Investigating the Institutional Landscape for Urban Water Security in Nepal
}

\author{
Chandra Lal Pandey, ${ }^{1}$ Gyanu Maskey, ${ }^{2}$ Kamal Devkota, ${ }^{3}$ and Hemant Ojha ${ }^{4}$
}

\begin{abstract}
Achieving water security is one of the major global challenges in the age of climate change, urbanization, rapid population increase, and weak water institutions. Despite the proliferation of water institutions and policies at national and local levels, the slow response to address water scarcity remains a puzzle in Nepal. This study investigated the state of water insecurity in relation to institutional structures, particularly focusing at the local level in Nepal. A qualitative research approach was used in two case study cities: Dhulikhel in central Nepal and Dharan in the east. The study found that failing to achieve water security is not due to a lack of an abundant supply of physical water in the country; rather, the problem is more about resolving the institutional complexity resulting from the existence of multiple water institutions with overlapping and competing roles and responsibilities. The authors conclude that strengthening institutional capacity is the key, including some fundamental rethinking to ensure clearly articulated and complementary roles, responsibilities, and relationships.
\end{abstract}

Keywords: institutions; Nepal; urban; water scarcity

\section{Introduction}

Water scarcity in Nepal looms large despite plentiful water resources. A number of large rivers flow southward from the Northern Himalayas, including about 6,000 rivers and rivulets that flow through Nepal, making it one of the richest countries in the world for water resources. Despite this abundance, achieving water security has become an increasingly serious problem for Nepal, as well as for other South Asian countries. ${ }^{1,2}$

According to Nepal's Department of Water Supply and Sanitation, an esti- mated 86.45 percent of the total population has access to drinking water but only an estimated 15 percent are served with quality drinking water. ${ }^{3}$ The poor and other excluded groups in urban areas have either limited or no access to sufficient quantity and basic quality drinking water and have to rely on springs, streams, tube wells, wells, and small brooks running from the mountains; they spend hours collecting water.

Water rationing is the norm in all big and small cities of Nepal since the cities are not able to provide enough potable water for household consumption. The drinking water sup- plied by one of the main water supply institutions-Nepal Water Supply Corporation (NWSC) - is not always safe for the end users as it is often contaminated and impure. ${ }^{3}$ While the demand for water is increasing significantly in urban centers, access to safe and adequate drinking water is becoming a challenge, especially in the context of changing climate and unplanned urban development compounded by slow responses from existing multiple institutions related to water management. ${ }^{4}$

The situation in Nepal illustrates that the physical availability of water does

\footnotetext{
'Program Coordinator and Assistant Professor of Community Development Program, School of Arts, Kathmandu University, Kathmandu, Nepal.

${ }^{2} \mathrm{PhD}$ candidate, Department of Development Studies, School of Arts, Kathmandu University, Kathmandu, Nepal.

${ }^{3}$ Senior Research Officer, Southasia Institute of Advanced Studies, Kathmandu, Nepal.

${ }^{4}$ Adjunct Associate Professor, University of Canberra, Canberra, Australia.
}

(C) Chandra Lal Pandey et al., 2019; Published by Mary Ann Liebert, Inc. This Open Access article is distributed under the terms of the Creative Commons License (http://creativecommons.org/licenses/by/4.0), which permits unrestricted use, distribution, and reproduction in any medium, provided the original work is properly credited. 
not necessarily mean that the population of the country has access to clean and adequate water for domestic purposes. This is particularly critical in urban centers where there is an immense gap between supply and demand of water. Rapid urbanization, urban population growth, urban living practices and changes in lifestyle, have together increased water demands, turning less water-consuming societies to more water-consuming societies. However, studies have shown that the multitude of water institutions and city authorities pay limited attention to sustainable urban water management, ${ }^{5-8}$ and South Asian cities remain particularly underprepared to address urban water scarcity in the face of ever-intensifying impacts of climate change. ${ }^{7-11}$

Previous research has explored urban water scarcity in developed countries but significantly less attention has been given to the challenges of sustainable urban water management in small and mid-sized cities of leastdeveloped countries like Nepal. ${ }^{12-15}$ This article discusses urban water issues currently faced by the emerging cities of Nepal, a country where freshwater resources are abundant yet institutional inaction threatens the future of urban water security. The authors argue that sustainable urban water management in Nepal is stymied despite having adequate water supplies because the myriad waterrelated institutions are riddled with competing, conflicting, and overlapping roles and responsibilities, and because local-level micro-politics get in the way of enacting effective policies from local to national levels.

\section{Institutions as the Key to Water Security}

An institution refers to organized and established procedures, which are represented as constituent rules of society, or "rules of the game." 16 Institutions can be either formal or informal. Institutions are defined basically as "the rules of the game in a society, or more formally, the humanly devised constraints that shape human action." ${ }^{\prime 7,18}$ Formal laws, rules, regulations and procedures, and informally-established patterns of behavior, norms, practices, and procedures form part of the institutional framework as the informal practices also become rules in their own right when they are accepted by the society. Institutions embody a combination of laws, rules and regulations, policies and objectives, operational plans and procedures, organizational bylaws and core values, incentive mechanisms, accountability mechanisms and norms, traditions, practices, and customs. North succinctly refers to institutions as the "framework within which human interaction takes place."17

In the literature, two types of institutions are identified as being involved in the management of water resources. The formal and informal institutions define and fashion the behavioral roles of individuals and groups in a given context of human interaction, aiming at a specified set of objectives. ${ }^{19,20}$ The key characteristics of institutions are exhibited by their patterns of norms and behaviors, which persist because they are valued and useful. ${ }^{19}$ The coexistence of informal and formal institutions is inevitable, but if the informal rules contradict the formal rules, the informal rules may become dysfunctional. ${ }^{20}$

Institutions are vital for the successful management of water resources because they are the link that governs the relationship between social and natural systems. ${ }^{21,22}$ According to Elinor Ostrom, institutions can be defined as the sets of working rules used to determine who is eligible to make decisions in some arena, what actions are allowed or constrained, what aggregation rules will be used, what procedures must be followed, what information must or must not be provided, and what payoffs will be assigned to individuals dependent on their actions. ${ }^{22}$

Discussions around resource-based institutions have also held a prominent place since Garrett Hardin argued in his seminal paper "The Tragedy of the Commons" that resource users in shared resource extraction and use systems are inevitably locked into the trap of destroying the resource on which they depend. ${ }^{23}$ Ostrom and colleagues note that the debate around institutional arrangements for resource management has been pinned on whether or not this "Tragedy of the Commons" prophesy is universally true, or if enough examples can be found to counterargue the proposition identifying favorable institutional processes that resolve these shared-resource problems. ${ }^{24}$ While Hardin proposed polarized solutions of either socialism or privatization of free enterprise, ${ }^{23}$ Ostrom continues to chart a number of alternative methods of restricting access and creating incentives that resolve overexploitation issues related to shared resources that are open to public consumption. ${ }^{22}$

Ostrom and Hardin have primarily focused on small-scale communitybased management of natural resources for sustainable use in rural settings, which may contribute very little to large-scale national, regional, and local-scale management of water resources with stakeholders interested in multiple uses of water. ${ }^{25}$ There is a need for research into understanding how governance of water institutions 
can improve water security in developing countries beyond smallscale community-managed natural resources in a rapidly urbanizing world. Some studies have also strongly suggested the need to improve water governance $e^{26,27}$ and water institutional arrangements and procedures of planning and decision making for achieving urban water security. ${ }^{28}$

The relevant literature has identified four different approaches to institutional water resources management ${ }^{29-32}$ - the activities of source conservation, planning, development, and distribution-which suggest that proper and efficient water management requires establishing effective institutional and government systems. Prior to the 1970s, water resource management was shaped by a hydraulic paradigm that approached water management mainly as a technical and scientific problem to be managed by experts. The top-down nature of this approach, according to the critics, gave insufficient attention to the complex, multi-scalar interrelationships among material and technical factors on the one hand, and the political, economic, and social institutions that shape human behavior, on the other. ${ }^{30}$ The economic dimension was the only consideration of hydraulic policy makers, which effectively sidelined social and human factors. In addition, there were a number of implementation issues with the bureaucracy not being ready to embrace participatory and integrated values. But the development of deep tube-wells for groundwater extraction came to be the panacea for water-related issues, making the people self-reliant by enabling them to use individual coping strategies.

Integrated water resources management (IWRM) was introduced as a new water governance/institutional approach in the late 1980s and early 1990s and was supported by major global development organizations. The aim of IWRM was to manage water as ecological units like river basins and watersheds, and also effectively coordinate across diverse water needs to ensure equitable, economically sound, and environmentally sustainable management of water resources and provision of water services. Despite the goals, the progress of IWRM has been very slow and has not been able to lead to a major transformation in water governance. ${ }^{29}$ Furthermore, the framework of IWRM involved making major changes in the existing interactions between politics, law, regulations, institutions, and civil society. ${ }^{14,33}$

The concept of Sustainable Water Resources Management (SWRM) emphasizes the need to consider the present as well as the long-term future of water resource systems that are managed to satisfy the changing demands placed on them without system degradation. ${ }^{34}$ Sustainable water resource management maintains its ecological, environmental, and hydrological integrity and fully contributes to the objectives of society, now and in the future. ${ }^{31,32}$ Sustainable water resource systems are those designed and operated in ways that make them more adaptive, robust, and resilient to changes. ${ }^{34}$ Because sustainable systems may fail, in the face of changes with uncertain impacts, an evolving and adaptive strategy is a necessary condition of sustainable water resource management. ${ }^{35}$

Adaptive Management (AM), considered to be a timely extension of IWRM, was developed to cope with major challenges of water management due to the increasing uncertainties caused by global climate change and rapid changes in socio- economic boundary conditions. ${ }^{36}$ Underlying the application of AM to river basins, in which the aim is to increase their adaptive capacity, is a profound understanding of the key factors that determine a basin's vulnerability. This approach advocates for more attention to understanding and managing the transition from current management regimes to more flexible regimes that take into account the environmental, technological, economic, institutional, and cultural characteristics of river basins. ${ }^{36}$

The foregoing review of the literature demonstrates the challenges ahead for water management institutions, which lack coordination and have overlapping jurisdictions and contradictory rules and regulations. Because the hydraulic paradigm focuses on the technical aspects of water management, it assumes that extraction of groundwater is based on water demand management; however, it does not focus on sustainable supply-side management. Approaches like IWRM, SWRM, and AM prioritize basin level, sustainable management practices, taking into account environmental, technological, and economic institutions without considering the changing contexts of emerging threats like climate change and the relationships between existing social and political institutions and water institutions. Efficient water management institutions can and should focus on both supply and demand side management without degrading the water sources in the face of climate change and the social and political dynamics of water institutions.

With this backdrop, the authors mapped out key water-related institutions and their policies, interactions, influence, prospects, and limitations in the two case study sites to explore what factors are contributing to the 
slow response to making these cities water secure. The study included an analysis of: 1.) national/state waterrelated institutions and water policy/ regimes of Nepal; 2.) local waterrelated institutions and policies of Nepal; 3.) informal institutions involved in water management and decision making, including local micropolitics of water management; and 4.) public experiences captured through interviews and focus group discussions and field observations.

\section{Research Design and Case Study Sites}

This case study was conducted in Dharan and Dhulikhel, which are a representative sample of the complex and diverse range of water institutions at the community and the city level. Dharan is located in eastern Nepal in Sunsari District and is situated at the foothills of the Mahabharata Range, which lies to the north; its southern border is adjacent to the Terai region. According to recent restructuring of the governance system following the 2015 Constitution, Nepal was divided into seven provinces. Dharan sub-metropolitan city of Sunsari District lies in Province 1 and consists of 20 wards covering an area of $192.32 \mathrm{~km}^{2}$. According to the 2011 Central Bureau of Statistics (CBS) report, it had a total population of 119,915 but its current population is 137,705 , with population density $716 / \mathrm{km}^{2}{ }^{37}$

Dhulikhel is located in the mid-hill region of east-central Nepal. Dhulikhel is part of the Kavre Valley, which is comprised of Dhulikhel, Banepa, and Panauti, and is a major urban center. Dhulikhel municipality lies in Province 3 covering an area of $55 \mathrm{~km}^{2}$ and consisting of 12 wards. According to CBS, it had a total population of 16,263 but with expansion of Dhulikhel territory the current total population is 32,162 with population density $585 / \mathrm{km}^{2}{ }^{37}$

Dharan is a foothill city and Dhulikhel is a hilltop city. Both are emerging commercial centers with a high rate of urban expansion, and both are experiencing rapid population growth due to rural-urban migration, as is also the case for other cities in Nepal. A burgeoning population means a rising demand of basic services that these cities are not wellprepared to address. The combined challenges of rapid and unplanned urbanization, population growth, and climate change exacerbate the impacts on water resources and water management. While large rivers flow from the surrounding areas of these cities, creating an abundance of groundwater at the macro-scale, Dharan and Dhulikhel face acute water scarcity with increasing gaps between water demand and supply, and quantity and quality. ${ }^{4}$

\section{Data}

A qualitative approach to primary data collection and analysis was complemented by a thorough literature review of the role of institutions for water management. Over the course of three years of field study, 28 individuals were interviewed (14 from each city), including elected officials and bureaucrats from the municipality, officials from Nepal Water Supply Corporation, Dharan and Dhulikhel Drinking Water User Committees, and water users from upstream and downstream communities, water board members, women, and marginalized people from target locations such as squatter settlements in Dharan. Three focus group discussions were also conducted in each city; groups included various and differentiated urban water users and managers, among others.

In the data collection process, participants shared reflections and experiences that had not otherwise been widely communicated in other forums

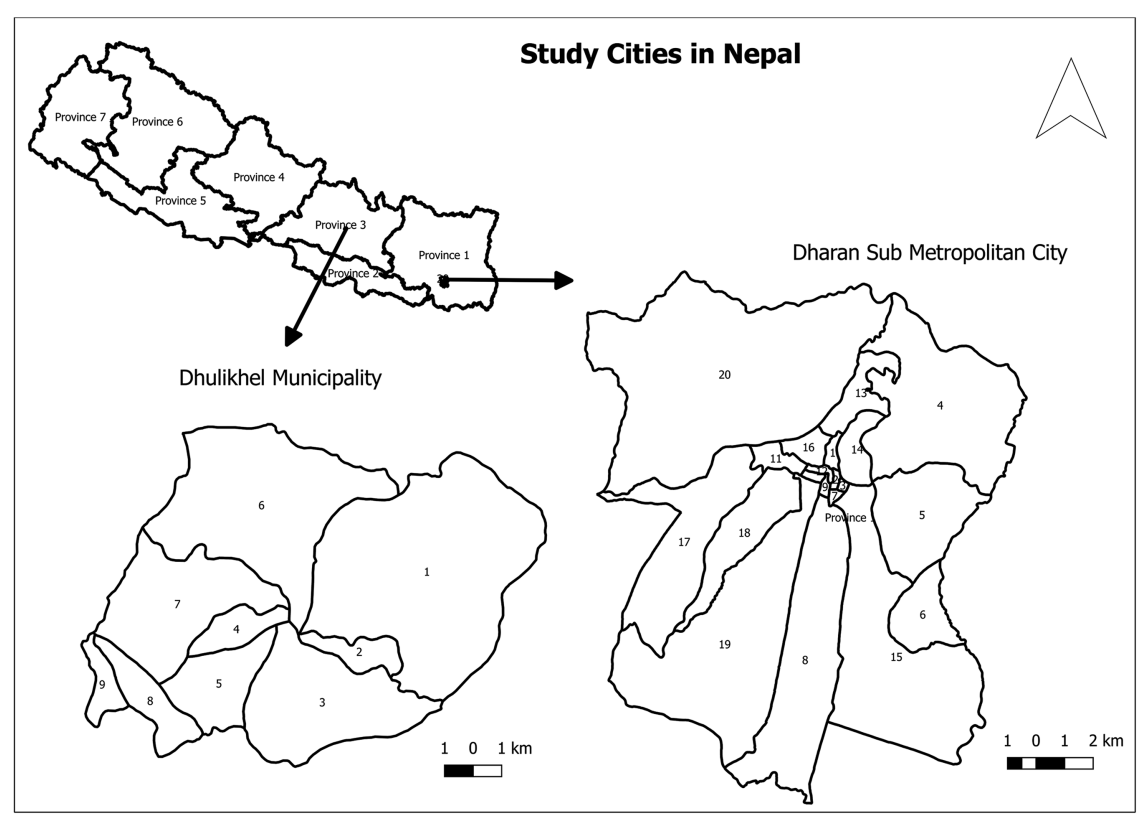

Figure 1. Federal Republic of Nepal: case study cities Dharan in Province 1 and Dhulikhel in Province 3 
sponsored by water institutions. These participants were critical of institutional planning, procedures, decisionmaking systems, and infrastructure. The data is presented as anonymous quotes and composite quotes that convey the opinions of multiple participants where opinions were broadly shared. The data is presented on three thematic topics that emerged during the analysis phase: 1.) clarity on institutional roles and responsibilities, 2.) integrated water policy, and 3.) capacitate water institutions.

\section{Water Management Institutions in Nepal}

Through the enactment of National Water Plan 2005, Nepal adopted integrated water resources management (IWRM) as the key approach for managing water. The plan notes that traditional water resources management, with its focus on the supply side and technical solutions, led to the development of drinking water supply and sanitation, hydropower, flood control, and other guidelines for use. Because evaluation was primarily focused on economic criteria, environmental and social impacts were not fully considered. Independent sector authorities mostly controlled these projects on the basis of 'command and control,' resulting in isolated projects, inter-sectoral, interregional, and riparian conflicts. ${ }^{38}$

Nepal has numerous categories of water-related institutions, classified as national, regional, district, municipal, and informal. The Water and Energy Commission Secretariat (WECS) is the central institution and it plays a crucial role in institutional and policy decisions related to the water sector. According to WECS, there are, inter alia, 18 acts, 10 regulations, one plan, three policies, three strategies and guidelines, four formation orders, three treaties, seven bilateral minutes, and two Memoranda of Understanding related to water management. ${ }^{39}$ These documents have enabled several institutional mechanisms to manage and monitor the use of water for drinking, irrigation, and hydropower development, among other uses, across different levels of jurisdiction.

The Water Supply and Sewerage Board, established in 1973 under the 1957 Development Board Act, was followed in 1985 by the establishment of the Water Supply and Sewerage Corporation under the Corporation Act of 1965. In 1990, the Nepal Water Supply Corporation (NWSC) was established as a public utility whose objective was to improve drinkingwater supply services in urban areas. Additional regulations-the Water Resources Act (WRA) in 1992, Water Resources Regulations (WRR) in 1993, Drinking Water Regulation (DWR) 1993, and the National Water Supply and Sanitation Policy (NWSSP) 2014-introduced important new actors, institutions, and policies for water management. The WRA (1992) prioritized drinking water and domestic uses, and opened avenues for people interested in using water resources for collective benefits on an institutional basis by allowing them to form a Water Users Association (WUA). The WRA (1993) developed the procedures for the formation of WUAs and established District Water Resource Committees for licensing WUAs. It also set up a dispute settlement mechanism for water-use service charges. DWR (1998) was established to regulate the use of drinking water, register and license drinking water under control of WUAs, control water pollution, and maintain drinking water quality.
The 2006 Water Supply Management Board Act set up a Water Supply Management Board (WSMB) to manage water in the municipalities or urban centers. The board has been authorized to prepare and apply water management plans, conserve sources, and fix and apply tariffs within its service area. In 2014, the NWSSP was established to oversee water supply and sanitation issues in urban and rural areas. Its objectives included protection of drinkingwater sources, conservation of the catchment areas of urban and rural water supply sources, and creation of an appropriate environment to enable private sector participation in urban water supply delivery.

Although the rules and regulations established in various water related policies and institutions, including WRA (1992), WRR (1993), DWR (1998), NWSSP (2014), and WSMB (2006), contradict and compete with one another, the already-established existing laws were not nullified and no clear demarcation of the roles and responsibilities between the existing institutions and new institutions were developed. Instead, one after another, many institutions were established with competing and overlapping roles, having little focus on the key element of National Water Plan (2005), which is the integrated water resources management (IWRM) approach. Although Biswas $^{33}$ asserts that IWRM is already a failed approach for water management, it has nevertheless now been universally accepted as a tool that combines IWRM and AM to manage the tasks related to sustainable water resource development. IWRM tries to reconcile multiple, competing uses for water, and attain legitimacy through broad public participation that includes social, technical, and political actors. $^{40}$ 


\section{Insights from Case Studies}

These case studies illustrate that at least three domains of institutions are crucial in understanding and addressing urban water insecurity: 1.) clarity on institutional roles and responsibilities, 2.) integrated water policy, and 3.) capacitated water institutions.

\section{Institutional Roles and Responsibilities}

Both Dharan and Dhulikhel have formal and informal water institutions. The formal institutions of water management in Dharan are NWSC, DWSMB, Dharan, and Dharan sub-metropolitan city. In Dhulikhel formal institutions are DDWUC, Dhulikhel Municipality, and Kavre Valley Drinking Water Supply Management Board (KVWSMB). The NWSC of Dharan is governmentmanaged whereas Dhulikhel's DDWUC is managed by a WUA. The Drinking Water Supply Management Board Act of 2006 established both the DWSMB (Dharan) and (Dhulikhel) KVWSMB, but both institutions conflict with all the existing policies and institutional practices. The informal institutions include various small water-user groups, women's networks, self-management (individual and institutional users), bottled water, water tankers, and nongovernmental organizations in both cities.

Prior to enactment of the Local Government Operations Act (LGOA) in 2017 and the formation of DWSMB (Dharan) and KVWSMB (Dhulikhel), the DDWUC (Dhulikhel) and NWSC (Dharan) were the key managers of a large portion of the water in Dhulikhel and Dharan, respectively. However, the establishment of water boards envisioned the existing WUAs, like DDWUC, and corporations, like NWSC, would be be merged gradually into newly- formulated water boards in Dharan and Dhulikhel, a process that has ignited conflicts between existing water providing institutions, water boards, and newly empowered institutions including the local government. The proposition to merge NWSC (Dharan) with DWSMB is highly contested within Dharan's population and is generally considered an unwelcome proposal for NWSC, Dharan. ${ }^{41}$

In Dhulikhel, substantial tensions have arisen due to a lack of coordination between DDWUC and the municipality, and DDWUC has been unwilling to agree to merge with the newly formed KVWSMB. In fact, the coordination gap between submetropolis, NWSC, and Dhulikhel municipality and the newly formed water boards have often generated confusion and conflicting outcomes in both cities. Shifting the responsibilities to one another due to lack of clarity in their prescribed roles has become the standard operation procedure for now. ${ }^{42}$

An analysis of interviews conducted by the authors with stakeholders of Dharan revealed that there are multiple institutions engaged in the water management of the town; however, they do not coordinate and interact with each other. Rather they hold grievances against one another through micro-politics, creating a non-amicable relationship. ${ }^{43}$ For example, as an overt case of the institutional conflicts, there is a lawsuit filed at the Supreme Court of Nepal by NWSC (Dharan) against the initiative of Dharan sub-metropolitan city and DWSMB, which are forcing NWSC to merge with DWSMB. ${ }^{44}$ In the context of Dhulikhel, DDWUC is not able to provide water services to all the wards of the municipality and the focus of DDWUC remains at the core of city only; however, DDWUC officials are not interested in merging with KVWSMB to expand the coverage in semi-peripheral and peripheral wards/areas. ${ }^{45}$

\section{Integrated Water Policy}

The case studies vividly exposed the layers of conflict among urban watermanagement institutions like WUAs, WSMBs, and municipalities in both cities due to competing, conflicting, and overlapping roles between and among these institutions, generated by various conflicting water-related policies, including WRA (1992), WRR (1993), DWR (1998), and NWSSP (2014). These conflicts strongly suggest a need for substantive participatory deliberations for making cities water secure. For the effective design and implementation of climate-informed integrated water resource policies, not only is effective coordination and collaboration between and among the existing urban water related institutions essential, but key policies and institutions at the federal level need substantive and timely revisions to reflect the changing dynamics of supply and demand management of water, and to negotiate the competing, conflicting, and overlapping roles of these policies and institutions. ${ }^{46}$

As indicated by the case studies, there is a need to develop an integrated water resources policy that considers the key characteristics of IWRM, SWRM, and AM approaches. Such a policy must prioritize basin-scale sustainable supply and demand side management without degrading the water sources and while meeting the emerging challenges of changing climate and the social and political dynamics of water institutions.

\section{Capacitated Water Institutions}

The case studies found a number of challenges, including conflicts between 
institutions, issues of funding, inequitable water distribution practices, exclusion of marginalized people from participation in decision making, and the potential negative future prospects due to the impacts of climate change, rapid population growth, and haphazard urbanization. The investigation in Dharan and Dhulikhel found that current practices of institutions and governance are promoting inequitable water distribution systems and favoring wealthy and powerful water users at the expense of others. ${ }^{47}$ The decision-making roles have been limited to DDWUC in Dhulikhel and NWSC in Dharan. However, neither the public nor the municipalities or the wards have any say or decision-making authority.

Insights from the interviews revealed that until recently there had been one institution in each city engaged in water management and the decisionmaking practices were not participatory and inclusive. However, as the water boards and municipalities emerged with newly empowered roles for urban water management, they have not been coordinating and interacting with one another. Therefore, institutional capacity with understandings regarding the threats of climate change on water resources, and the impact of changing population and urbanization on sustainable urban water management needs to be promoted. ${ }^{48}$

The most common responses of interview subjects and focus group discussion participants in both Dharan and Dhulikhel suggested that the favored way to address water scarcity is through source conservation and reform of institutions. The focus group participants in Dharan suggested that effective implementation of climate-adaptive sustainable water management could be accom- plished by effective coordination between Dharan sub-metropolitan city, Dharan Water Board, ward level local body offices, and water-related institutions and communities, which become essential for implementing initiatives like rainwater harvesting and recharge pits. ${ }^{49}$ Likewise, stakeholders from Dhulikhel shared that proper infrastructural planning, including developing storage tanks, proper installation of appropriate supply pipes, effective implementation of regulations, effective management, and grievance redress by the institutions were the key areas that could effectuate water governance reforms in Dhulikhel. ${ }^{50}$

\section{Conclusion}

An investigation of local water management institutions in Nepal shows that multiple and interlocking institutional mechanisms, including the involvement of communitymanaged and government-managed water institutions, shape water management practices and outcomes related to sustainability and equity. While institutions may have aimed to evolve to lend resilience to water management, multiple water institutions, from the national to local levels, have overlapping, competing, and conflicting roles, often functioning in parallel to one another. Such a lack of synergy has diminished the capacity of institutions to focus on challenges of urban water scarcity; indeed much of the institutional energy is wasted on keeping their legacies intact. Such institutional overlapping and complexity has limited the creation of to institutional innovations for adaptation to climate change and for managing haphazard urbanization which is partly attributable to rapid urban population growth. Strengthening institutional capacity is the key to urban water management, along with some fundamental rethinking to ensure clearly articulated and complementary roles, responsibilities, and relationships.

\section{Acknowledgment}

The authors acknowledge the research support provided by Southasia Institute of Advanced Studies Under its IDRC-funded project Climate Adaptive Water Management Plans for Cities in South Asia.

\section{Author Disclosure Statement}

No competing financial interests exist.

\section{References}

1. Immerzeel $\mathrm{W}$, van Beek $\mathrm{L}$, and Bierkens M. Climate change will affect the Asian water towers. Science 2010;328(5984):1382-1385.

2. Mirza MQ, and Ahmed QK (eds.). Climate Change and Water Resources in South Asia. Routledge, London, 2005.

3. Government of Nepal (GoN). Nepal Water Supply, Sanitation and Hygiene Sector Development Plan 2016-2030. Kathmandu, 2016.

4. Pandey C, and Bajracharya R. Climate adaptive water management practices in small and mid-sized cities of Nepal: Case studies of Dharan and Dhulikhel. Sustain J Record 2017;10 (5): 300-307.

5. Aylett A. Institutionalizing the urban governance of climate change adaptation: Results of an international survey. Urban Clim 2015;14 (1):4-16. http://dx.doi.org/10.1016/j. uclim.2015.06.005 (last accessed 5/ 27/2019).

6. Chiplunkar A, Seetharam K, and Tan C (eds.). Good Practices in Urban Water Management: Decoding Good Practices for a Successful Future. 
Asian Development Bank, National University of Singapore, 2012.

7. Shrestha S, Aihara Y, Yoden K, et al. Access to improved water and its relationship with diarrhoea in Kathmandu Valley, Nepal: A crosssectional study. BMJ Open 2013;3:1-8. 8. Subhadra B. Water: Halt India's groundwater loss. Nature 2015;521 (7552):289-289.

9. Kumar MD. Managing Water in River Basins: Hydrology, Economics, and Institutions. Oxford University Press, New Delhi, India, 2010.

10. Cullet P, and Gupta J. India: Evolution of water law and policy. In Dellapenna JW, Gupta J, and UNESCO-IHW (eds.), The Evolution of the Law and Politics of Water. Springer, 2009, pp. 157-173.

11. Saleth RM, and Dinar A. Water Challenge and Institutional Response: A Cross-Country Perspective. Policy Research Working Paper Series 2045. The World Bank, Washington, DC, 1999.

12. Hoekstra AY, Buurman J, and van Ginkel KCS. Urban water security: A review. Environ Res Lett 2018;13:1-14.

13. Bakker K, and Morinville C. The governance dimensions of water security: A review. Philos Trans A Math Phys Eng Sci 2013;371(2002): 20130116. http://dx.doi.org/10.1098/ rsta.2013.0116 (last accessed 5/27/ 2019).

14. Rogers $\mathrm{P}$, and Hall AW. Effective Water Governance. Global Water Partnership Technical Committee No.7, Sweden, 2003.

15. Cronin AA, Prakash A, Priya S, et al. Water in India: Situations and prospects. Water Policy 2014;16 (3):425-441.

16. Jepperson RL. Institutions, institutional effects, and institutionalism. The new institutionalism in organizational analysis. In Powell WW, and
DiMaggio PJ (eds.), The New Institutionalism in Organizational Analysis. University of Chicago Press, 1991, pp. 143-163.

17. North DC. Institutions, Institutional Change and Economic Performance. Cambridge University Press, Cambridge, England, 1990, pp. 3, 4. 18. Lachmann LM. The Legacy of Max Weber. Glendessary Press, Berkeley, CA, 1971.

19. Merrey DJ. Institutional contexts for managing irrigated agriculture. In Abernethy C (ed.), International Irrigation Management Institute Workshop Proceedings, Chiang Mai, Thailand, Nov. 1-5, 1993, Colombo, Sri Lanka. The Institutional Framework for Irrigation, 1996, pp. 7-22.

20. Bandaragoda DJ, and Firdousi GR. Institutional factors affecting irrigation performance in Pakistan: Research and policy priorities. International Irrigation Management Institute (IIMI), Colombo, Sri Lanka, 1992. (IIMI Country Paper Pakistan 4).

21. Kramer A, Wolf AT, Carius A, et al. The key to managing conflict and cooperation over water. A World of Science 2013;11(1): 4-12. http://unes doc.unesco.org/images/0021/002191/ 219156E.pdf (last accessed 5/27/2019). 22. Ostrom E. Governing the Commons: The Evolution of Institutions for Collective Action. Cambridge University Press, Cambridge, England, 1990.

23. Hardin G. Tragedy of the commons. Science 1968;162 (3859):12431248.

24. Ostrom E, Burger J, Field C, et al. Revisiting the commons: Local lessons global challenges. Science 1999;284 (5412):278-282.

25. Pandey C. International Climate Change Governance: Issues of Democracy, Institutions and the Media. University of Waikato, Hamilton, New Zealand, 2014.
26. Rijke J, Farrelly M, Brown RR, et al. Configuring transformative governance to enhance resilient urban water systems. Environ Sci Policy $(2013 ; 25: 62-72$.

27. Van de Meene SJ, Brown RR, and Farrelly MA. Towards understanding governance for sustainable urban water management. Glob Environ Change 2011; 21:1117-1127.

28. Lundqvist J, Appasamy P, and Nelliyat P. Dimensions and approaches for Third World city water security. Phil Trans R Soc Lond B Biol Sci 2003;358 (1440):1985-1996. 29. Pahl-Wostl C. Water governance in the face of global change. From understanding to transformation. Springer International, Cham, Switzerland, 2015.

30. Molle, F. Water, politics and river basin governance: Repoliticizing approaches to river basin management. Water Int 2009;34 (1): 62-70.

31. American Society of Civil Engineers (ASCE). Sustainability Criteria for Water Resource Systems. ASCE, Reston, VA, 1998.

32. United Nations. Water, a Shared Responsibility: The United Nations World Water Report 2. UNESCO and Berghahn Books, Paris and New York, 2006. http://www.unesco.org/new/ en/natural-sciences/environment/ water/wwap/wwdr/wwdr2-2006 (last accessed 5/30/2019).

33. Biswas AK. Integrated water resources management: A reassessment. Water Int. 2004;29: 248-256.

34. Loucks D, Stakhiv E, and Martin L. Sustainable water resources management. J Water Resour Plann and Manag 2000;126(2): 43-47.

35. Holling CS (ed.). Adaptive Environmental Assessment and Management. John Wiley \& Sons, New York, 1978.

36. Pahl-Wostl C, Downing T, Kabat $\mathrm{P}$, et al. Transition to Adaptive 
Water Management: The NeWater Project. NeWater Working PaperX, Institute of Environmental Systems Research, University of Osnabrück, Osnabrück, Germany, 2005.

37. Central Bureau of Statistics. National Population and Housing Census 2011. Government of Nepal, Kathmandu.

38. Government of Nepal. National Water Plan 2005. Kathmandu.

39. Government of Nepal. Water and Energy Commission Secretariat (WECS). 2018. http://www. wecs.gov.np/ (last accessed 5/27/ 2019).

40. World Water Council. A Discussion Paper of the World Water Council Task Force on IWRM.
World Water Council, Paris, France, 2015.

41. Interviews with NWSC officials, Dharan.

42. Interviews with officials of DDWUC, NWSC, and Dharan and Dhulikhel Municipalities.

43. Interviews with Dharan water users/citizens inclusive of Municipal and DDWSMB officials and focus group discussions, and data analysis of Dharan.

44. Interview with Deputy Mayor of Dharan and focus group discussions in Dharan.

45. Interviews with DDWUC officials, Ward Chairpersons of Dhulikhel, and focus group discussions in Dhulikhel.
46. Findings of focus group discussions from Dhulikhel and Dharan. 47. Interviews with ward chairpersons and focus group discussions in Dharan and Dhulikhel.

48. Interviews with deputy mayor of Dharan and DDWUC Manager of Dhulikhel.

49. Focus group discussion 4-Dharan 50. Interviews with KII in Dhulikhel

Address correspondence to: Dr. Chandra Lal Pandey Community Development Program School of Arts

Kathmandu University P. B No. 6250, Hattiban Lalitpur, Nepal

E-mail: chandra.pandey@ku.edu.np 